\title{
A study of social policies based on the example of the Bulgarian hotels on the Black Sea coast
}

\author{
Daniela Ventsislavova Georgieva ${ }^{1,{ }^{*}}$, and Teodora Marinova Georgieva ${ }^{1}$ \\ ${ }^{1}$ International business school - Botevgrad, 7 Vincent van Gogh Str., Bulgaria
}

\begin{abstract}
.
Research background: The implications of globalisation for social policy have been highly debated at the specialised literature. Social policies as an element of corporate responsibility reports (CSR) is neglected compared to environmental information. This can have a negative effect on the sustainability and development of industries directly dependent on their staff. Such sector in Bulgaria is the tourism where at the national level, the main challenge is the adequate parallel development of human resources as they underlie tourist product construction and development.

Purpose of the article: The main aim of the study is to analyse factors that impact on the disclosed staff-related social policies at the financial statements of hotel enterprises in the territory of Varna and Burgas Black Sea regions in Bulgaria. The factors under analyses are the size of the organisation, available external audit control, available foreign participation in the capital, applicable accounting standards, accounted result (profit or loss); enterprise category.

Methods: The adopted research methods are logical, deductive and comparative methods, methods of analysis and synthesis. To verify the author hypotheses the IBM - SPSS Statistics software is used.

Findings \& Value added: The results of the study show that comparatively high percentage of the enterprises do not publish staffrelated information. This could lead to harmful effects to globalisation based on asymmetry in the data, problems with recruitment of qualified staff, unjustified economic decisions by data users. From all factors, under review, the strongest calculated statistic relationship is between the external audit control and staff-related disclosures.
\end{abstract}

Keywords: Disclosures; Social Policy; Staff; Hotel Enterprises; Factors; Financial Statements

JEL Classification: $M 140 ; M 480 ; M 490$

\footnotetext{
*Corresponding author: dgeorgieva@ibsedu.bg
} 


\section{Introduction}

The term globalisation can be analysed as the process of interaction and integration among people, companies and governments in many contexts, incl. social, economic, geographical, political, technological, financial, cultural, etc. in micro- and macroeconomic aspect. Without belittling the importance of all aspects of the globalisation main object of study is the social-economic side. The literature provides evidence of the impact of the globalisation to the social policy. They are primarily related to employment effect through job creation and welfare, labour-saving effects of the new technologies brought about by multinational firms, mobility and convergence, human rights, coordination of national laws, policies and practices in the field, and so on $[1,2,3]$. In this aspect, globalisation is perceived as a prerequisite for the development of the entire world society by eliminating differences and borders. This is achievable by harmonisation and standardisation of the regulatory framework. From an economic point of view, harmonisation has a significant role when comparing financial statements of enterprises, in the elements of which (accounting policy, annexes, appendixes, reports, etc.) are given the opportunity to disclose non-financial information of socio-economic nature. These disclosures are used by stakeholders (external and internal to enterprises) for sound economic decision-making.

In terms of a pandemic situation, and the closure of borders worldwide, large parts of the economic sectors were severely affected in 2020. Tourism is among the most affected economic sectors by Covid-19 crisis. This requires the adoption of efficient and effective measures and policies, especially in terms of attracting and retaining highly qualified and trained staff who can meet the new requirements and expectations of customers. Such policies are part of the enterprises' corporate social responsibility ((CSR) or so-called social responsibility). The European Commission has defined the CSR of enterprises as their impact on society by introducing a process to integrate social, environmental, ethical, human rights and consumer concerns into their business operations and core strategy [4]. This should be done in close collaboration with stakeholders to maximise shared value for the management staff of the organisation, shareholders and society, as well as to identify, prevent and mitigate any adverse impacts. [5]. In addition, human resources are essential for achieving and maintaining sustainable business success. Even so, the subject of more detailed information on the scope of CSR is environmental rather than social policies [6]. Researches in the field also argue for a lack of consistency in the accounting methodology for reporting social responsibility, as well as problems in the scope of reporting and activities undertaken $[7,8,9]$. This leads to gaps in staff information, human rights, the sustainability of supplier relationships and other data [10], which in turn leads to significant gaps between the planned CSR policy and its actual implementation [11]. This, in hand, is a subject of criticism and discussions [12, p. 40].

The main object of the study is published information in the financial statements of hotel enterprises (including the attached appendices, significant accounting policies, activity reports, auditors' reports and other documents) about the adopted and implemented staff-related social policies. The target group covers enterprises that own and manage hotels and carry out operations in the territories of Varna and Burgas regions. This territorial choice is based on the reported data on growing accommodations in the two Black Sea tourist regions (Varna and Burgas), partly justified by the presence of a robust territorial concentration of overnight stays of foreigners [13, p. 18, 37]. The main goal of the research is to analyse factors that affect disclosed staff-related social policies at the financial statements of hotel enterprises in the territory of Varna and Burgas Black Sea regions in Bulgaria. The factors under analyses are the size of the organisation; available external audit control; available foreign participation in the capital; applicable accounting standards; accounting financial result (profit or loss); enterprise category. The adopted research 
methods are logical, deductive and comparative methods, methods of analysis and synthesis. To verify the authors' hypotheses the IBM - SPSS Statistics software is used. The results of the study support the literature by making a more in-depth analysis of the factors that influence the disclosure of staff-related social policies by hotels. This can be seen as a prerequisite for achieving sustainability in tourism, based on harmonisation and standardisation in published data, which are used for financial and economic analysis, and hence have a beneficial effect on globalisation.

\section{Literature review and the author's hypotheses}

One of the most widely used methods of CSR evaluation is social reports (sustainable development reports or corporate citizenship reports) [14, p. 156], based on the practice of public "reporting" by the use of websites [15, p. 117]. Even though there are many suggested concepts that support the organisations in structuring the content and indicators of their social reports $[15,16,17,18,19]$, low levels of publication of CSR data on the websites of Bulgarian hotels is reported [15]. Therefore and due to the fact that currently in Bulgaria there is no uniform format for corporate social responsibility of hotels, nonfinancial reporting, as an element of financial statements of organisations, develops and elaborates further actions of CSR in the business practice [20, p. 26]. In this context, staff data are an element of disclosure in the annexes to the annual financial statements (AFS) of organisations. The impossibility of comparative analysis, due to non-disclosures, both between the reports of individual companies or between the reports by years of the same company, is fundamental for the creation of asymmetric information and reflects on their comparability. The lack of comparability has a negative impact on globalisation. In this respect, the main goal of the paper is to analyse some significant factors influencing the disclosure of data in the annual financial statements. For this research, only mandatory disclosure is under analyses. Mandatory disclosures are directly related to the regulatory requirements of the accounting standards, which are applicable in a respective country and therefore are fundamental for sound financial analysis. Publishing data for the same indicators at micro-level could help to converge the policies of the countries and their mutual interests. This is done by attracting investments and creating conditions for easier access to markets, based on correct comparative analyses of the financial statements of enterprises.

It is argued that enterprises should have an equal level of mandatory disclosure of information in accordance with the adopted accounting standards (national or international) [21, p. 392]. However, the literature provides evidence that due to the wide variety of disclosures, there is a lack of textual homogeneity on published data, reflecting on a lack of international homogeneity [22]. Therefore, the authors perceive the chosen accounting basis in the preparation of financial statements by enterprises, as a factor that affects the disclosure.

Internationality is a factor that influence the applicable CSR policies of companies. In the specialised literature, internationalisation is defined as listed companies [23]. We believe that such an assumption can be made for countries where stock markets are developed. Due to several factors, such a hypothesis cannot be made for Bulgaria. We believe that the presence of foreign investors in the equity of a hotel may also put more pressure on the level of disclosure. This is due to the cultural and legislative diversity of shareholders and the need for more financial and non-financial data for their analysis needs.

If the statement is audited by an independent external auditor, this is an indicator of its reliability and clarity. Furthermore, the level of disclosure is a factor measuring the quality of audit services, which leads prestigious audit companies to encourage their clients to disclose more data in their statements [24]. 
Literature supports the idea that there is a direct relationship between company size and disclosures [24]. This is because regulations, visibility, social responsibility and external control are higher for large companies rather than for smaller ones. In addition, large companies are more organised, have more resources to create detailed data and benefit more from disclosures than smaller organisations.

Companies that report higher profits are more ambitious and want to publish more textual data in terms of quality and quantity. This suggests that companies with poor performance try to hide it from shareholders and investors by disclosing less information [21, p. 400, 25, p. 258].

For establishment and registration of an enterprise whose primary business activity is in the hotel field, the following types of merchants in Bulgaria are relevant: sole proprietors who are natural persons and companies (general partnership, limited partnership, limited liability company, sole-proprietor limited liability company, joint-stock company, partnership limited by shares). The type of merchant predetermines the legal relations with partners and their rights, participants in the company, the liability of the founders, etc. The founders and the partners in their capacity as stakeholders can affect the design, application and control of social policies.

Based on the above, the following hypotheses are formulated:

(H1) There are statistical relationships and correlations between mandatory staff-related disclosures in the financial statements of hotel enterprises and the accounting standards selected for their preparation.

(H2) There is a statistical relationship between the mandatory staff-related disclosures and the presence of foreign participation in the capital of hotel enterprises.

(H3) There are statistical relationships and correlations between the presence of independent financial audit by a registered auditor and the mandatory staff-related disclosures in the financial statements of hotel enterprises.

(H4) There are statistical relationships and correlations between the category of the enterprise and the mandatory staff-related disclosures.

(H5) There are statistical relationships and correlations between the mandatory staffrelated disclosures in the financial statements and the accounted result (profit or loss).

(H6) There are statistical relationships and correlations between the type of merchant and the mandatory staff-related disclosures in the financial statements.

\section{Methodology of the study}

For the research, an analysis of the financial statements of 452 enterprises is made. Excluded from the scope of the target group are organisations that are in the process of liquidation, have been deregistered, legal entities with no published financial statements, newly registered, hotels having published data for only one year without the possibility of comparative analysis, as well as those that do not offer hotel services in the territory of Varna and Burgas. Organisations that own more than one hotel operating in both areas are surveyed only once, regardless of the number of hotels they control. The final sample includes 100 enterprises. Published financial statements and data in the Commercial Register and the Register of Non-Profit Legal Entities of March 2020 is used. The analysed reports are for 2015 due to a lack of more up-to-date information for some entities from the target group. IBM - SPSS Statistics, ver. 19 software is used, and the test of statistical relationships and correlations is based on Chi-square - analysis $(\chi 2)$. As a contingency coefficient, the Cramer's coefficient $(\mathrm{V})$ is chosen. The variables that are subject to analysis are coded using two values 1 (one) - to present the existence of occurrence and 2 (two) - to explain the absence of occurrence. From the previously introduced approach for coding the 
variables, an exception is made for the category of the enterprise and its legal form, where the values of 1 (one) up to 4 (four) represent micro, small, medium and large enterprises.

\section{Results of the analysis}

When it comes to the legal form, $35 \%$ of the analysed enterprises are limited liability companies, $35 \%$ are sole-proprietor limited liability companies, $19 \%$ are joint-stock companies, and $11 \%$ are sole-proprietor joint-stock companies. The majority (43\%) are small enterprises, $31 \%$ are micro-enterprises, $20 \%$ are medium-sized enterprises, and only $6 \%$ represents large enterprises. Based on the requirements of the Bulgarian Accounting Act effective in 2015, International Accounting Standards (IAS) have been adopted and applied as an accounting basis for the preparation of financial statements by $26 \%$ of the hotels under review. According to the legislator, there is a group of companies applying National Accounting Standards (NAS), which are allowed to prepare a simplified format of financial statement. The Accounting Act allows those enterprises to prepare only a balance sheet, a profit and loss statement, and an appendix. Only sole merchants falling within the scope of some of the hypotheses of the Accountancy Act are not required to attach an accounting policy (part of which covers staff-related accounting information) as an element of the constituent part of AFS in part Appendix. However, none of the analysed organizations is a sole trader, which is why they are required to apply accounting policies as part of their statements. In addition, organizations applying IAS should also have explanatory notes to their financial statements, containing a statement of compliance, a summary of significant accounting policies, supporting information about the items presented in the financial statements, and other relevant data for understanding the annual financial statements. Based on the fundamental nature and purposes of the accounting policy to support the correct, fair, truthful, neutral and full presentation of the information in the financial statements, we believe that it is a mandatory element of the statement. However, $27 \%$ of the target organizations do not publish annexes, accounting policies or any textual data with financial or non-financial nature. Among the other enterprises, only $49 \%$ disclose staff-related information in the notes to the financial statements. This is indicative of non-publication of narrative information to the users of the statements, which is crucial for sound economic decision-making.

Based on the collected data when testing the first research hypothesis, the chi-square value is 11.295 , with a level of significance $\alpha=0.05$ and degree of freedom $n=2$. Upon these values and fulfilled all conditions of the Chi-square analysis, we can reject the null hypothesis and accept the existence of an average statistical relationship (Cramer's V: $0.336, \mathrm{p}<0.05)$ between the publication of mandatory staff-related disclosures by the enterprises under review and the chosen accounting base (NAS or IAS).

No statistical relationships is calculated between foreign participation in the capital of the analysed hotels and the mandatory staff-related disclosures. In this case, the theoretical value is higher than the empirical one, and the level of significance is higher than the error. This gives us a reason to reject the alternative hypothesis and to accept the null one (see Table 1). The analysis of the collected data is essential to exclude foreign participation in the capital as a factor that influences the staff-related disclosure by the hotel enterprises.

When testing for statistical relationships and dependencies between the staff-related disclosures and the existence of audit control by an independent external auditor, average dependencies are calculated. All conditions for the application of the chosen methodology are fulfilled. More precisely, based on the results shown in Table 1, the calculated empirical value is 26.913, with theoretical value 5.99, the level of significance is $\alpha=0.05$ and the degree of freedom is $n=2$. 
Based on the collected and analyzed data (see Table 1) between the category of enterprises and the published significant staff-related accounting policies there is also a statistical relationship (chi-square value is 21.588 , with a level of significance $\alpha=0,05$ and degree of freedom $\mathrm{n}=6$ ). The calculated statistical relationship is average (Cramer's V: $0.329, \mathrm{p}<0.05$ ). Still, not all conditions for the Chi-square test application are fulfilled, which is a prerequisite for being sceptical when accepting such statistic relationship (in 4 cells $(33.3 \%)$ there are values of theoretical frequencies which are smaller than 5).

There are no statistical relationships and dependencies between the reported accounting financial result and the mandatory staff-related disclosures. The theoretical value is higher than the empirical one, and the level of significance is higher than the error (see Table 1).

There are no statistical relationships and dependencies between the mandatory staffrelated disclosure and the legal status of the enterprise (once again, the theoretical value is higher than the empirical one, and the level of significance is higher than the error).

Table 1. Cross tabulation data when testing the research hypotheses for statistical relationships and dependencies.

\begin{tabular}{|c|c|c|c|c|c|c|}
\hline $\begin{array}{c}\text { Hypothe } \\
\text { ses }\end{array}$ & $\begin{array}{c}\text { Pearson } \\
\text { Chi- } \\
\text { Square } \\
\text { value }\end{array}$ & $\begin{array}{c}\text { Level of } \\
\text { significance }\end{array}$ & $\begin{array}{c}\text { Degree of } \\
\text { freedom }\end{array}$ & $\begin{array}{c}\text { Asymp. } \\
\text { Sig. (2- } \\
\text { sided })\end{array}$ & $\begin{array}{c}\text { Cramer's } \\
\text { V value }\end{array}$ & $\begin{array}{c}\text { Approx. } \\
\text { Sig }\end{array}$ \\
\hline $\mathrm{H} 1$ & 11.295 & $\alpha=0.05$ & $\mathrm{n}=2$ & .004 & .336 & .004 \\
\hline $\mathrm{H} 2$ & 0.289 & $\alpha=0.05$ & $\mathrm{n}=2$ & .866 & .054 & .866 \\
\hline $\mathrm{H} 3$ & 26.913 & $\alpha=0.05$ & $\mathrm{n}=2$ & .000 & .519 & .000 \\
\hline $\mathrm{H} 4$ & 21.588 & $\alpha=0.05$ & $\mathrm{n}=6$ & .001 & .329 & .001 \\
\hline $\mathrm{H} 5$ & 5.192 & $\alpha=0.05$ & $\mathrm{n}=4$ & .268 & .161 & .268 \\
\hline $\mathrm{H} 6$ & 10.987 & $\alpha=0.05$ & $\mathrm{n}=6$ & .089 & .234 & .089 \\
\hline
\end{tabular}

Source: (own calculations, $\mathrm{n}=100$ )

\section{Discussion}

The results of the study are indicative for a low level of publication of non-financial data, incl. social policies in the financial statements of Bulgarian hotel enterprises. It is notable that companies do not publish fully the required mandatory disclosures. Based on the analyzed factors that influence the disclosures, it can be pointed out that the ones with the strongest impact are those having a legislative and control nature. In this respect, the development and implementation of staff-related CSR do not aim to create the professional capacity of the human resources departments in the organizations. This gives us reason to conclude that hotels' disclosure regarding their staff does not aim to support the processes of globalization. As the main reasons (but not only) it can be pointed out:

- The lack of effective control over the published appendices to the financial statements of enterprises. In this case, the state control is mainly focused at compliance with the 
requirement for on-time preparation of the financial statements, as well as the correct calculation of enterprises' taxes.

- The attitude of the management staff towards the disclosure of staff-related data. Here we refer to the management's desire to hide information that could be used against the organization by its competitors or the Labor Inspectorate.

- The long-term strategy of the organization. If an organization wants to enter international markets, it will face the need to harmonize the regulatory framework, attract investment, create a positive image and trust in society, build accountability to meet the information needs of internal and external data users.

- The understanding of the employees in the organization (including the compilers of the statements) about the role of CSR on the long-term sustainability and development of the organization based on the human factor.

The stated reasons for non-publication of CSR are mainly focused on the attitude of users and compilers of statements regarding staff-related disclosures. Due to its limitations, the present study cannot answer whether and to what extent they affect the accountability of hotels. Because of the need for proper accountability as a mechanism for creating appropriate conditions for economic globalization, it is relevant and useful further researches regarding the attitude towards such disclosures to be made.

\section{Conclusions}

The calculated statistical relationships between the factors under review and the staffrelated disclosures are prerequisite to conclude that only the accounting base chosen by the organizations and the presence of an audit by an external independent auditor has an average impact on the published textual information. These two factors are nearly related to specific legal requirements for control and reporting, which confirms the thesis that the disclosures are primarily aimed at implementing the regulatory framework, rather than supporting the activities and strategies of hotels. When testing the research hypotheses, no statistical relationships are calculated between the staff-related disclosures and 1) foreign participation in the capital of enterprises and 2) the accounted financial result for the period. Possible reasons can be sought in the overall attitude of the management staff to the published information. In this case, investors and managers focus on quantitative rather than textual data that can be used for financial and economic analysis purposes. Although in recent years there has been an emphasis on textual and non-financial data, the principle "demand determines supply" should not be forgotten. In other words, if users of the statements show little or no interest in staff-related disclosure, companies may choose to "miss" it. Although based on the used data, the average statistical relationship between the size of the enterprise and the disclosures are reported, such conclusion should not be considered completely true due to unfulfilled criteria for application of the chosen research methodology.

A relatively high percentage of enterprises in the target group does not publish staffrelated information. Such non-disclosure can be associated with many negative assumptions about the organizations, such as attempted fraud; lack of qualified human staff; neglection of CSR as an opportunity to build competitive advantage and attract an educated workforce; ignorance to the regulatory framework; lack of efficient management, etc. The consequences of such assumptions may be related to an increase of distrust in hotels, the outflow of human capital to foreign hotel companies, reduction of investment in the sector, building a negative public opinion and attitude towards the sector. This is directly related to the sustainability of tourism, and in the current economic, health and social crisis it may cause many hotels to close doors, which in hand have a negative impact 
on the globalization. During a viral pandemic period, part of the public requirements for hotels will be focused not only on the renewal of assets related to sanitary and hygienic reasons but also on providing better service and care to customers. This will require hotel's staff to have additional skills and competencies, which is essentially motivated not only by the company's remuneration policy but also by the overall attitude and social environment in the organization. The lack of a written, published and applied staff-related social policy by hotels can be a prerequisite for labour turnover and unsustainable development.

Acknowledgements: This study is financed with funds under the project "Model Development and Testing for Monitoring and Evaluation of Sustainable Tourism Development in Bulgaria (after the example of national resorts)" financed by the National Fund "Scientific Research ", contract No КП$06-\mathrm{H} 25 / 3$ from 13.12.2018.

\section{References}

1. Rhodes, M. (1996). Globalization and the West European Welfare States: A Critical Review of Recent Debates. Journal of European Social Policy, 6(4), 305-327.

2. Swank, D. (2002). Global Capital, Political Institutions and Policy Change in the Developed Welfare States. Cambridge: Cambridge University Press.

3. Ghose, A. K. (2003). Jobs and Incomes in a Globalizing World. Geneva: International Labour Office.

4. European Commission (2020). Retrieved from: https://ec.europa.eu/growth/industry/corporate-social-responsibility_en.

5. European Commison (2019). Commission Staff Working document - Corporate Social Responsibility, Responsible Business Conduct, and Business and Human Rights: Overview of Progress, SWD(2019) 143 final, Brussels.

6. Sheldon, P. J., Park, S.Y. (2011). An exploratory study of corporate social responsibility in the US travel industry. Journal of Travel Research, 50, 392-407.

7. Holcomb, J. L., Upchurch, R. S., Okumus, F. (2007). Corporate social responsibility: What are the top hotel companies reporting? International Journal of Contemporary Hospitality Management, 19, 461-475.

8. Burns, P. M., Cowlishaw, C. (2014). Climate change discourses: How UK airlines communicate their case to the public. Journal of Sustainable Tourism, 22(5), 750-767.

9. Bonilla-Priego, M. J., Font, X., Pacheco, R. (2014). Corporate sustainability reporting index and baseline data for the cruise industry. Tourism Management, 44, 149-160.

10. Perez, A., Rodriguez Del Bosque, I. (2014). Sustainable development and stakeholder relations management: Exploring sustainability reporting in the hospitality industry from an SD-SRM approach. International Journal of Hospitality Management, 42, 174-187.

11. Font, X., Walmsley, A., Cogotti, S., McCombes, L., Hausler, N. (2012). Corporate social responsibility: The disclosure-performance gap. Tourism Management, 33, 1544-1553.

12. Weston, R., Guia, J., Mihalič, T., Prats, L., Blasco, D., Ferrer-Roca, N., Lawler, M., Jarratt, D. (2019). Research for TRAN Committee - European tourism: recent developments and future challenges. European Parliament, Policy Department for Structural and Cohesion Policies, Brussels.

13. National Strategy for Sustainable Development of Tourism in the Republic of Bulgaria. Updated version 2014-2030. 
14. Nikolov, E. (2017). Otsenka na socialnata otgovornost na balgarskite proizvoditeli na velosipedi. Upravlenie na znanieto, informatsiata i ikonomicheskia rastezh. Almanah nauchni izsledvania, 24, part II.

15. Atanasova, L. (2014). Korporativna socialna otgovornost na hotelite v Bulgaria: e li tya instrument za internet marketing?. Upravlenski praktiki, BFU, 1, 117-126.

16. Global Reporting Initiative. (2013). The external assurance of sustainability reporting. Amsterdam, The Netherlands; The International Integrated Reporting Council. The International $<\mathrm{IR}>$ Framework.

17. Directive 2014/95/EU of the European Parliament and of the Council of 2014 amending Directive 2013/34/EU as regards disclosure of non-financial and diversity information by certain large undertakings and groups, Official Gazette of the European Union L 330.

18. Hopkins, M. (2005). Measurement of corporate social responsibility. International journal of management and decision making, 6(3-4), 213-234.

19. Gorcheva, T., Lyubenov, Z., Savcheva, V. (2013). Realizirane na korporativnata socialna otgovornost - savremenni izmerenia. Dialog. INI, extraordinary thematic, 2, 12-26.

20. Bakardzhieva, R. (2018). Korporativnata socialna otgovornost v konteksta na globalnata veriga na dostavki. Busines posoki, 2, 25-38.

21. Teixeira Da Silva, S., A. Morais, Curto, J. (2013). Disclosure of R\&D activities. Global Business Perspectives, 1(4), 391-417.

22. Gelb, D. S. (2002). Intangible assets and firms' disclosures: An empirical investigation. Journal of business finance \& accounting, 29(3-4), 457-476.

23. Meek, G. K., C. B. Roberts, Gray, S. J. (1995). Factors influencing voluntarily annual report disclosure by US, UK, and continental European multinational corporations. Journal of international business studies, 26(3), 555-572.

24. Jones, S., Higgins, A. D. (2006). Australia's switch to international financial reporting standards: A perspective from account preparers. Accounting and Finance, 46(4), 629652.

25. Nguyen, L. S., Manh, D. T., Hong, N. T. H., Le, Q.H. (2017). Factors affecting disclosure levels of environmental accounting information: the case of Vietnam. Accounting and Finance Research, 6(4), 255-264. 